\title{
Sideoats Grama Growth Responses to Seasonal Fires and Clipping
}

\author{
R. James Ansley, ${ }^{1}$ Michael J. Castellano, ${ }^{2}$ and William E. Pinchak ${ }^{3}$ \\ Authors are ${ }^{1}$ Professor, ${ }^{2}$ Research Associate, and ${ }^{3}$ Associate Professor, Texas Agricultural Experiment Station, \\ PO Box 1658, Vernon, TX 76384.
}

\begin{abstract}
There is increased interest in the use of summer-season fires to limit woody plant encroachment on southern prairie grasslands, but collateral effects of these fires on grasses are poorly understood. We quantified effects of repeated winter fires, repeated summer fires, simulated grazing (clipping), and their interaction on yields of the $\mathrm{C}_{4}$ midgrass, sideoats grama (Bouteloua curtipendula) in northern Texas. Monoculture patches of sideoats grama were exposed to 1 of 3 fire treatments: 1) no burn, 2) 2 winter fires in 3 years, or 3) 2 summer fires in 3 years; and to 1 of 2 clip treatments (no clip or clip once each spring). Total yield (live + standing dead), live yield, percent live tissue, and foliar cover were measured in spring and late-growing season (late-season) over a 7-year period. In unclipped plots, late-season total yield did not fully recover until 2 growing seasons after winter fires and 3 growing seasons after summer fires. By 5 years postfire, total yield was greater in both fire treatments than in the no burn. Live yields recovered more quickly than total yields following summer fires but never exceeded the no burn. Percent live tissue was greater in both fire treatments than in the no burn for up to 2 years postfire. Clipping reduced total and live yields in the no burn and winter-fire treatments but not in the summer-fire treatment. By 5 years postfire, total and live yields were greater in the summer fire + clip than the no burn + clip or winter fire + clip treatments. Results suggest that 1 ) sideoats grama is tolerant of summer fires but full recovery may require at least 3 years, and 2) in the long-term, summer fire + clipping may stimulate sideoats grama production more than winter fire + clipping or clipping alone.
\end{abstract}

\section{Resumen}

Hay creciente interés de usar fuego en verano para limitar la expansión de plantas leñosas en los pastizales del sur, pero, los efectos colaterales de estos fuegos sobre los zacates son pobremente entendidos. En el norte de Texas, cuantificamos los efectos de fuegos repetidos en invierno, fuegos repetidos en verano, apacentamiento simulado (cortes) y sus interacciones en el rendimiento de zacate C4 "Sideoats grama" (Bouteloua curtipendula). Parches de monocultivo de "Sideoats grama" fueron expuestos a 1 de 3 tratamientos de fuego: 1) sin quema, 2) 2 fuegos en invierno en 3 años, y 3) 2 fuegos en verano en 3 años; y a 1 de 2 tratamientos de corte (sin corte y un corte cada primavera). El rendimiento de biomasa total (viva + muerta), el rendimiento de biomasa viva, el porcentaje de tejido vivo y la cobertura foliar fueron medidos en primavera y al final de la estación de crecimiento durante un periodo de 7 años. En las parcelas sin corte, el rendimiento de biomasa total a fines de la estación se recuperó totalmente hasta 2 estaciones de crecimiento después de recibir los fuegos de invierno y hasta 3 estaciones después de recibir los de verano. Cinco años después del fuego, el rendimiento de biomasa total fue mayor en ambos tratamientos de fuego que en los no quemados. El rendimiento de biomasa viva se recuperó más rápidamente que el rendimiento de biomasa total después de los fuegos de verano, pero nunca excedieron a obtenidos en los tratamientos no quemados. El porcentaje de tejido vivo fue mayor en ambos tratamientos de fuego que en los sin fuego, esto ocurrió hasta por 2 años después del fuego. El corte redujo los rendimientos de biomasa total y viva en los tratamientos de sin quema y quema en invierno pero no en el de quema de verano. Cinco años después de aplicado el fuego los rendimientos de biomasa total y viva fueron mayores en el tratamiento de fuego en verano + corte que en los de sin quema + corte o fuego en invierno + corte. Los resultados sugieren: 1) que el "Sideoats grama" es tolerante a los fuegos de verano, pero su recuperación total puede requerir de al menos 3 años, y 2) a largo plazo, el fuego en verano + corte puede estimular la producción de "Sideoats grama" más que el fuego de invierno + corte o el corte solo.

Key Words: Bouteloua curtipendula, $\mathrm{C}_{4}$ grasses, grazing management, herbage production, prescribed burning, summer fire, woody plant encroachment

\section{INTRODUCTION}

This research was funded by USDA-NRICRGP Agricultural Systems Grant 94-04256 and the E. Paul and Helen Buck Waggoner Foundation, Vernon, Texas. The W. T. Waggoner Estate, Vernon, Texas, provided land area for the research.

Correspondence: R. James Ansley, Texas Agricultural Experiment Station, P0 Box 1658, Vernon, TX 76384. Email: r-ansley@tamu.edu

Manuscript received 21 May 2005; manuscript accepted 21 February 2006.
Restoration of fire regimes in grasslands encroached by woody plants has been the subject of worldwide interest (Wright and Bailey 1982; Axelrod 1985; Van Auken 2000; Bond et al. 2005; Briggs et al. 2005). In temperate grasslands, prescribed fires are often conducted during the dormant season (winter or early spring) because cooler air temperatures during this time facilitate a more controlled, manageable fire than those conducted during the growing season (i.e., "summer" fires), when 
higher air temperatures can increase fire intensity (Wright and Bailey 1982; van Wilgen et al. 1990). However, there has been increased interest in the application of summer fires in woodyencroached grasslands because the greater intensity and longer duration of high temperatures in summer fires inflict greater damage to woody plants than that caused by winter fires (Trollope 1987; Ansley and Jacoby 1998; Ansley and Taylor 2004). If summer fires are shown to be safe under well-defined fire prescriptions, more information will be needed regarding the responses of nontarget herbaceous species to summer fires alone and in combination with grazing.

$\mathrm{C}_{4}$ grass production usually recovers quickly after winter fires (Engle and Bidwell 2001) and is sometimes enhanced for 2-3 years following winter fires (Knapp et al. 1998). However, there is concern that summer fires may have long-lasting, detrimental effects on $\mathrm{C}_{4}$ grass production because those grasses are physiologically active during summer fires (Trollope 1984, 1987; Bailey 1988; Engle and Bidwell 2001). For example, in South Africa, Everson et al. (1985) and Trollope (1987) indicated that recovery of $\mathrm{C}_{4}$ Themeda triandra was significantly delayed by summer fire. In contrast, $\mathrm{C}_{4}$ grasses in the southern Great Plains of the United States may be more tolerant of summer fires (Engle et al. 1998; Engle and Bidwell 2001). Although the additive effects of herbivore grazing and fire are increasingly being investigated (Fuhlendorf and Engle 2004; Archibald et al. 2005), few studies have contrasted effects of seasonal fires (i.e., winter vs. summer fires) and grazing on ecosystem responses (Knapp et al. 1998).

In the southern Great Plains, summer fires are being considered for suppression of woody species, such as honey mesquite (Prosopis glandulosa Torr.) (Ansley and Jacoby 1998). Fire return interval in the southern Great Plains grasslands before European settlement may have been as frequent as every 2-3 years (Frost 1998), and many theorize that such high fire frequencies limited woody encroachment in this region (Axelrod 1985; Van Auken 2000). However, little empirical evidence is available regarding the effects of repeated summerseason fires on herbaceous vegetation in this grassland biome or the interactions between seasonal fires and grazing.

Here, we measure the response of the $\mathrm{C}_{4}$ midgrass, sideoats grama (Bouteloua curtipendula [Michx.] Torr.), to seasonal fires and simulated grazing. Sideoats grama is a commercially and ecologically important species throughout North America and, in particular, the southern Great Plains (Stubbendieck et al. 1992). Our objective was to compare effects of repeated winter fires, repeated summer fires, and clipping on aboveground growth (biomass yield and foliar cover) and physiological status (percentage of live tissue) of sideoats grama. We hypothesized that 1 ) winter fires will enhance sideoats grama yield (Knapp et al. 1998), 2) summer fires will reduce yield, and 3 ) the combined effects of summer fire and periodic defoliation by clipping (to simulate grazing) will reduce yields to a greater degree than that from summer fire or clipping alone.

\section{METHODS}

\section{Site Description}

Research was conducted in the northern Rolling Plains ecological area of Texas, south of Vernon (lat $33^{\circ} 51^{\prime} \mathrm{N}$, long $99^{\circ} 26^{\prime} \mathrm{W}$; elev. $381 \mathrm{~m})$. Mean annual rainfall is $665 \mathrm{~mm}$, with peak rainfall months in May $(119 \mathrm{~mm})$ and September $(77 \mathrm{~mm})$ (NOAA 2004). Mean monthly air temperatures range from an average daily maximum of $36^{\circ} \mathrm{C}$ in July to an average daily minimum of $-2.5^{\circ} \mathrm{C}$ in January. Growing season for $\mathrm{C}_{4}$ grasses is from April to October. Research plots were established in an area that was seeded to sideoats grama ('Premier' variety), in 1973, after honey mesquite had been removed by mechanical grubbing. The 'Premier' variety is a "semibunchgrass" growth form, with short rhizomes, originally from northern Mexico and which has adapted to west-central Texas (Thornburg 1982; TFSS 2005). Some honey mesquite $\left(<20 \mathrm{ha}^{-1}\right)$ had reestablished from seed in the plots and were 1-3 $\mathrm{m}$ tall when the current study began, but densities were not enough to impact herbaceous growth (Ansley et al. 2004). Native grass species also found at the site included $\mathrm{C}_{3}$ Texas wintergrass (Nasella leucotricha [Trin. \& Rupr.] Pohl.), $\mathrm{C}_{4}$ meadow dropseed (Sporobolus compositus [Poir.] Merr.), and $\mathrm{C}_{4}$ vine mesquite (Panicum obtusum H.B.K.). Soils are fine, mixed, thermic Typic Paleustolls of the Tillman series that are 3-4 m deep alluvial clay loams underlain by sandstone and shale parent material (Koos et al. 1962). Livestock grazing was excluded on the site since 1989.

\section{Treatments and Data Collection}

Nine vegetation patches, each dominated by 'Premier' sideoats grama (each patch $10-20 \mathrm{~m}^{2}$ ), were randomly located on level terrain and similar soil type. Three patches were not burned (no burn), 3 patches were subjected to repeated winter fires in 1993 and 1995 (w93w95), and 3 patches were subjected to repeated summer fires in 1992 and 1994 (s92s94). Winter fires were applied in February or early March, and summer fires were applied in September. Fires were applied as headfires using drip torches within bladed fireguards. Within each patch, 2 plots $(0.6 \times 0.9 \mathrm{~m})$, which initially had $>90 \%$ sideoats grama foliar cover, were permanently marked. In 1 plot, all herbaceous material (sideoats grama plus any other species) was clipped to a $5-\mathrm{cm}$ stubble height once each spring (May) for 5 years (1993-1997) to simulate a high-intensity, low-frequency grazing pattern. The other plot remained unclipped. Thus, both clipped and unclipped plots occurred within each fire treatment replicate. Once each year, within a week after each spring clipping event, a $0.5-\mathrm{m}$ border area was mowed around each of the clipped plots to reduce the competitive impact of surrounding vegetation.

Using the treatments described, 2 temporally separated experiments were conducted. Experiment 1 quantified effects of fire treatments alone on late-growing season (AugustSeptember) sideoats grama aboveground yield components: total yield (live + standing dead), live yield, and percentage of live tissue. Yield components were measured in the unclipped treatment by harvesting all aboveground tissue within a $0.25-\mathrm{m}^{2}$ quadrat that was located within $5 \mathrm{~m}$ of the marked $0.6 \times 0.9 \mathrm{~m}$ unclipped plot and resembled the unclipped plot in terms of percentage of foliar cover of sideoats grama. A different $0.25-\mathrm{m}^{2}$ quadrat was harvested each year. Experiment 1 quantified responses from 1993-1997.

Experiment 2 quantified effects of fire treatments alone, spring clipping alone, and the combined effects of fire and clipping on the same 3 yield components, with the exception that these data were collected each spring (May to early June). 
The same procedure described for Experiment 1 was used to quantify yield components in unclipped treatments. In the clipped treatments, yield components were measured by collecting the sideoats grama biomass that was clipped within the marked $0.6 \times 0.9 \mathrm{~m}$ plot. In the clipping portion of Experiment 2, the first year's sample measured all production after the first burn (summer 1992 or winter 1993); the clip treatment began in spring 1993, and all subsequent sample years measured standing biomass that had accumulated in the 1 year since the previous clip date. Experiment 2 quantified responses from 1993-1997 and again in the spring of 1999. Plots were not clipped in 1998 because of a severe drought and concerns that clipping would kill the plants. Noninvasive measures, such as foliar cover, were measured in 1998, however. Thus, the 1999 biomass data represented 2 years standing crop accumulation since the spring 1997 clip date.

Samples from both experiments were oven dried at $60^{\circ} \mathrm{C}$ to a constant weight and weighed. A subsample of each sample was used to separate live from dead tissue and to estimate live yield and percentage of live tissue. At study termination in May 1999 , all $0.6 \times 0.9 \mathrm{~m}$ plots (both clipped and unclipped) were clipped to estimate yield. Total and live yields were expressed as $\mathrm{g} \cdot \mathrm{m}^{-2}$. Sideoats grama foliar cover, foliar cover of other grass species, forb cover, litter cover, and bare ground as a percentage of total ground area were visually estimated in each $0.6 \times 0.9 \mathrm{~m}$ plot each year (except 1995). We did not experimentally compare effects of single fires vs. repeated fires of each season within the same postfire growing season because of a limited number of sideoats grama patches that were of sufficient size to accommodate the clipping treatments.

A few days before each burn, standing herbaceous fine fuel was estimated by clipping $5\left(0.25-\mathrm{m}^{2}\right)$ quadrats located randomly near the marked quadrats in each plot, oven drying at $60^{\circ} \mathrm{C}$ for 48 hours, then weighing. Air temperature, relative humidity, and wind speed were measured immediately before each fire. Peak fire temperature was recorded at 0,10 , and $30-\mathrm{cm}$ above the soil surface for each fire, using glass-insulated type $\mathrm{K}$ (Chromel-Alumel) thermocouple wire (20 AWG; $0.8 \mathrm{~mm}$ in diameter) and a data logger (after Ansley et al. 1998). Herbaceous fine fuel moisture content was measured by obtaining a wet weight of the clipped samples in the field immediately after clipping and comparing that to oven dry-weight. Percentage of moisture was calculated on a wet-weight basis ([wet wt - dry $\mathrm{wt}] /$ wet wt). Precipitation was recorded at the site.

\section{Statistical Analyses}

To evaluate effects of fire treatments alone on late-season yield components (Experiment 1; Hypotheses 1 and 2), repeated measures analyses of variance (ANOVA) were used with fire treatment (3 levels: no burn, w93w95, s92s94) and sample date ( 5 dates) as main effects and 3 replicates per treatment (SPSS 2003). The replicate within-fire treatment error $(\mathrm{df}=6)$ tested effect of fire treatment, and the pooled error $(\mathrm{df}=24)$ tested effects of date and fire treatment $\times$ date interactions. Five lateseason dates (1993-1997) were used in these analyses.

To evaluate effects of fire, clipping, and fire + clipping on spring yield components and cover variables (Experiment 2; Hypotheses 1-3), we used repeated measures ANOVA that included fire treatment (3 levels), clip treatment (2 levels), and sample date ( 6 dates) as main effects ( 3 replicates per treatment).
The replicate within-fire treatment error $(\mathrm{df}=6)$ tested effects of fire, the clip $\times$ replicate within-fire treatment error $(\mathrm{df}=6)$ tested effects of clip and fire $\times$ clip interactions, and the pooled error $(\mathrm{df}=60)$ tested effects of date and date $\times$ fire, date $\times$ clip, and date $\times$ fire $\times$ clip interactions. The 6 spring-sample dates (1993-1997, 1999) were used in these analyses.

For both sets of analyses, within-sample date post hoc analyses were performed if significant date $\times$ treatment interactions were found. Means were separated using Fisher's protected LSD $(P<0.05$ unless otherwise noted). Percentage data were arcsine-transformed and nonnormal data were $\log _{10}$-transformed before analysis.

In addition, as part of Experiment 2, we evaluated the relative "effect sizes" of fire treatment, clip treatment, springsample date, and the fire $\times$ clip interaction on yield components. Effect size (or partial $\mathrm{Eta}^{2}$; the proportion of the effect + error variance that is attributable to the effect; Tabachnick and Fidell 2001) was calculated for each treatment within the $3 \times 2 \times(6)$ repeated measures ANOVA using the equation:

$$
\eta_{p}^{2}=S S_{\text {effect }} /\left(S S_{\text {effect }}+S S_{\text {error }}\right)
$$

where $\eta_{p}{ }^{2}$ is the effect size, and $S S$ is the sums of squares. Subsequently, we determined these treatments' relative effect size on each response variable, during the first 2 years postfire in each repeated fire treatment (1993-1994 after the first fires and 1995-1996 after the second fires) and 3 and 5 years postfire (1997 and 1999), by dividing the $3 \times 2 \times(6)$ repeated measures ANOVA into a $3 \times 2 \times(4)$ and a $3 \times 2 \times(2)$ repeated measures ANOVA, and calculating the partial Eta ${ }^{2}$ for these additional analyses.

\section{RESULTS}

Annual precipitation was greater in the first 4 years of the study when the fires were applied (1992-1995) than in the last 4 years (1996-1999) (Fig. 1). Precipitation was well above average in 1995. Droughts occurred during the first half of 1996 and most of 1998.

Air temperature was lower during winter fires than summer fires, but relative humidity and wind speeds were similar among fire treatments (Table 1). Herbaceous fine fuel was similar between summer and winter fires, but fuel moisture content was greater in summer fires. Peak fire temperatures were similar between winter and summer fires. Duration of high temperature (seconds $>200^{\circ} \mathrm{C}$, for example) was greater in summer fires than winter fires (data not shown). Summer fires had greater flame heights and yielded more smoke than winter fires (R. J. Ansley, personal observation).

\section{Experiment 1: Effects of Fire Alone}

There were significant fire treatment $\times$ date interactions for late-season total yield and percentage of live tissue but not for live yield. However, there was a significant main effect of fire treatment on live yield. Total yield was greatest in the no-burn treatment and lowest in the summer-fire treatment, with winterfire treatment total yields intermediate for 2 years after the summer 1992 (s92) or winter 1993 (w93) fires (Fig. 2A). After the second set of fires in summer 1994 (s94) or winter 1995 


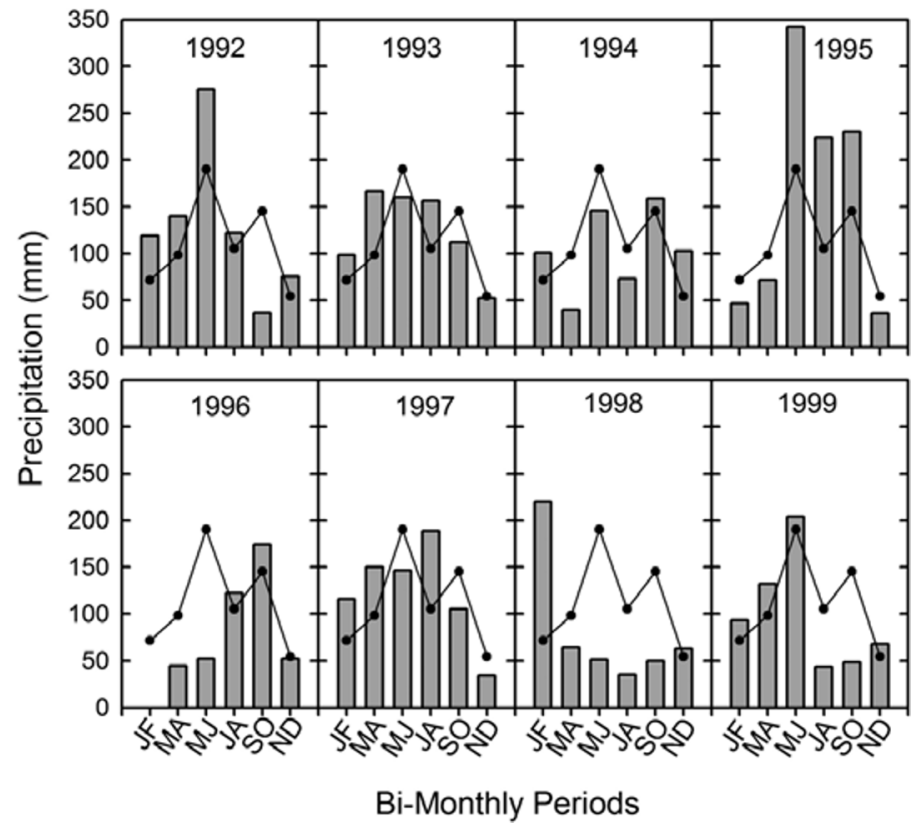

Figure 1. Bimonthly precipitation (bars) measured on site compared with the 30-y bimonthly average (line) (NOAA 2004).

(w95), total yield was lower in the summer-fire treatment than in the no-burn treatment during the first year postfire, but by 3 years postfire there was no difference in total yield between the 3 treatments (Fig. 2B). Total yield recovered to no-burn levels 2 years after the w95 fire and 3 years after the s94 fire but was never greater in burn treatments than in the no-burn treatment.

Live yield was lower in the summer-fire treatment than in the no-burn and winter-fire treatments 1 growing season after the first fires, but was similar among all treatments in all other years (Figs. 2C and 2D). Percentage of live tissue was greater in both fire treatments than in the no-burn treatment 2 growing seasons after the first fires (1994) (Fig. 2E). Following the second set of fires (s94, w95), percentage of live tissue was greater in the summer-fire treatment than in the other treatments the first growing season postfire (1995) but was greater in the no-burn treatment than in the 2 fire treatments in the third year postfire (1997) (Fig. 2F).

Experiment 2: Effects of Fire and Clipping. There were significant fire $\times$ clip $\times$ sample date interactions for all

Table 1. Fire date, air temperature (AT), relative humidity $(\mathrm{RH})$, wind speed (Wind), herbaceous fine fuel (HFF), and HFF moisture content (moist.) in unclipped areas and peak fire temperatures (temp) during the fire treatments (trt). All replicate plots were burned within minutes of each other, so weather data were recorded only once. Fine fuel and fire temperature data on each date are the mean of 3 plots.

\begin{tabular}{|c|c|c|c|c|c|c|c|}
\hline $\begin{array}{l}\text { Fire } \\
\text { trt }\end{array}$ & $\begin{array}{l}\text { Fire } \\
\text { date }\end{array}$ & $\begin{array}{l}\text { AT } \\
\left({ }^{\circ} \mathrm{C}\right)\end{array}$ & $\begin{array}{l}\mathrm{RH} \\
(\%)\end{array}$ & $\begin{array}{c}\text { Wind } \\
\left(\mathrm{m} \cdot \mathrm{s}^{-1}\right)\end{array}$ & $\begin{array}{c}\text { HFF } \\
\left(g \cdot m^{-2}\right)\end{array}$ & $\begin{array}{c}\text { HFF } \\
\text { moist. (\%) }\end{array}$ & $\begin{array}{c}\text { Avg. peak } \\
\text { fire temp }\left({ }^{\circ} \mathrm{C}\right)\end{array}$ \\
\hline w93 & 08 Feb 1993 & 22.2 & 26 & 4.2 & 424 & 11.9 & 726 \\
\hline w95 & 02 Feb 1995 & 27.2 & 31 & 6.4 & 444 & 15.9 & 709 \\
\hline s92 & 17 Sep 1992 & 33.9 & 34 & 2.2 & 380 & 34.3 & 723 \\
\hline s94 & 09 Sep 1994 & 31.7 & 42 & 4.0 & 461 & 23.8 & 635 \\
\hline
\end{tabular}

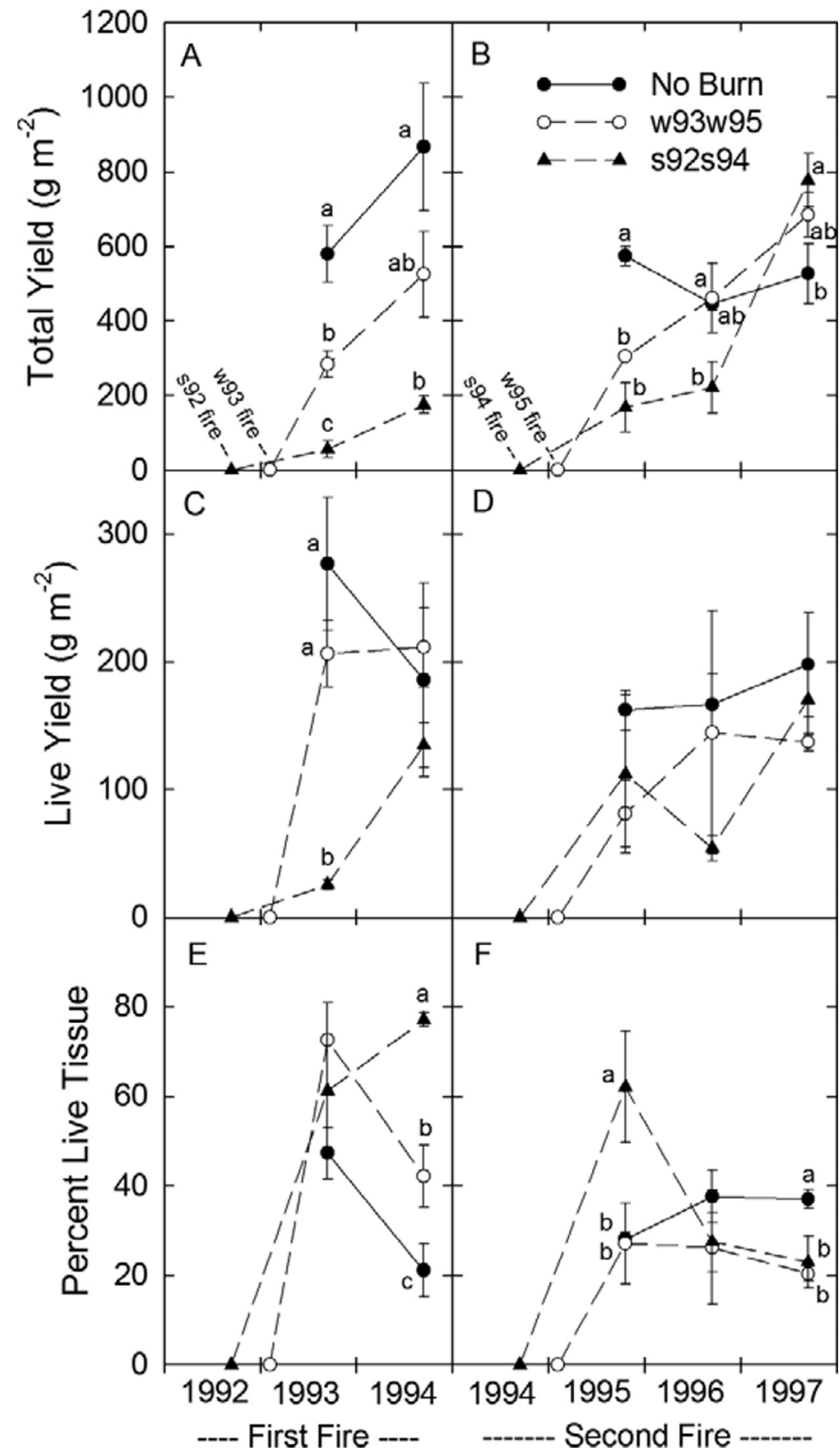

Figure 2. Sideoats grama late-season (Experiment 1; 1993-1997) total yield, live yield, and percentage of live tissue within unclipped treatments exposed to 2 sets of fire treatments. Different letters within each panel and sample date indicate significant differences among treatments; Fisher's protected LSD $(P<0.05)$. Vertical lines are \pm 1 SE. Zero values are provided to indicate times when summer 1992 (s92), winter 1993 (w93), summer 1994 (s94), and winter 1995 (w95) fires were imposed.

spring-season yield components. Spring total yield was initially lowest in the summer-fire treatments the first growing season after each fire (Figs. 3A and B) but increased over time to exceed the no burn in 1999 (Fig. 3B). Spring yield in the winterfire treatment also exceeded the no burn in 1999, 5 years after the w95 fire.

Clipping reduced total yields in the no-burn and winter-fire treatments on most sample dates after 1993 (Figs. 3A vs. 3C; 3B vs. 3D). In contrast, total yield in the summer-fire treatment remained similar between clipped and unclipped treatments 


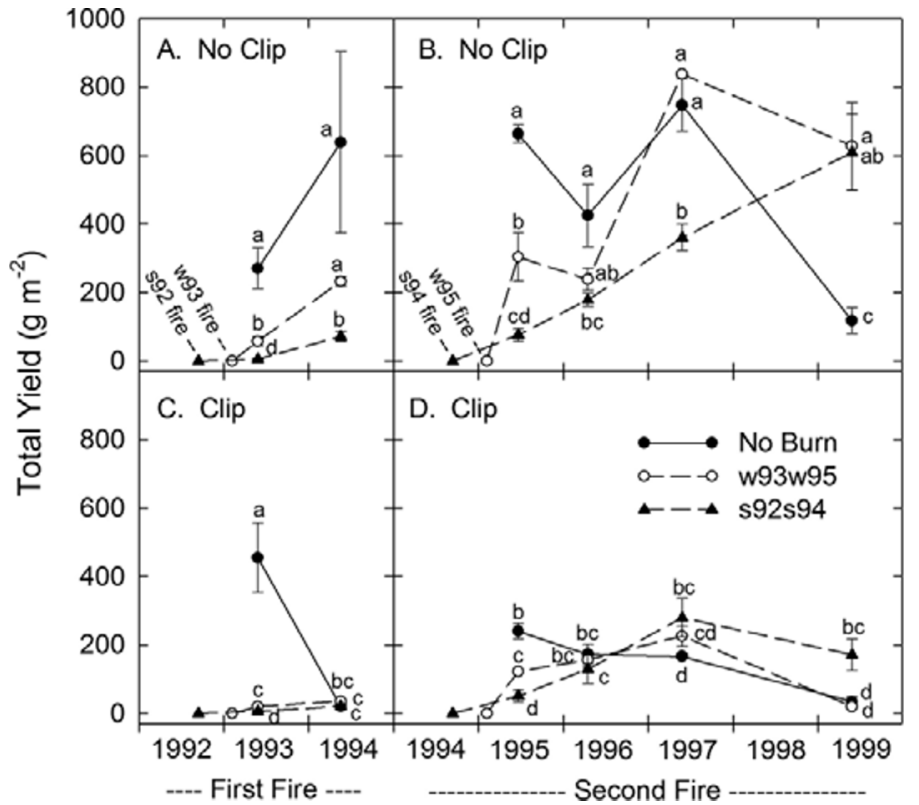

Figure 3. Sideoats grama spring-season (Experiment 2; 1993-1997 and 1999) total yield in unclipped and clipped treatments within fire treatments. Different letters across vertical panels within each year indicate significant differences between treatments; Fisher's protected LSD $(P<0.05)$. Vertical lines are \pm 1 SE. Other details are the same as in Figure 2.

until 1999. Comparing fire treatment effects in clipped plots, total yield was lower in both fire treatments than in the no-burn treatment at the first spring after the s92 or w93 fires (1993) (Fig. 3C) and at the first spring after the s94 and w95 fires

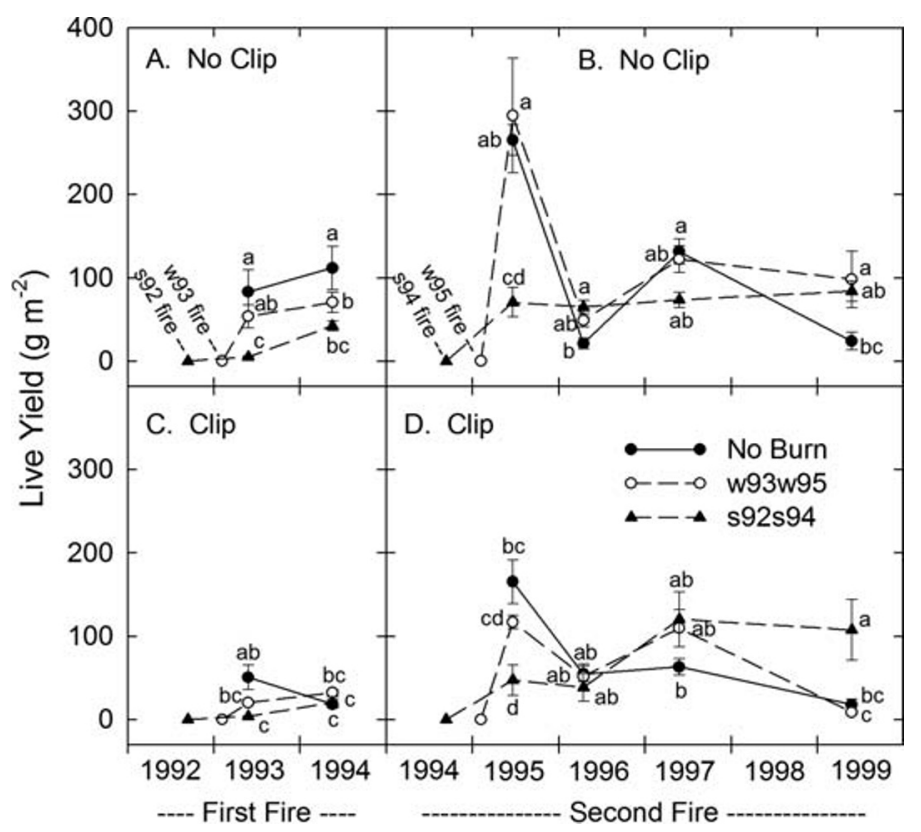

Figure 4. Sideoats grama spring-season (Experiment 2) live yield in unclipped and clipped treatments within fire treatments. Different letters across vertical panels within each year indicate significant differences between treatments; Fisher's protected LSD $(P<0.05)$. Vertical lines are $\pm 1 \mathrm{SE}$. Other details are the same as in Figure 2 .

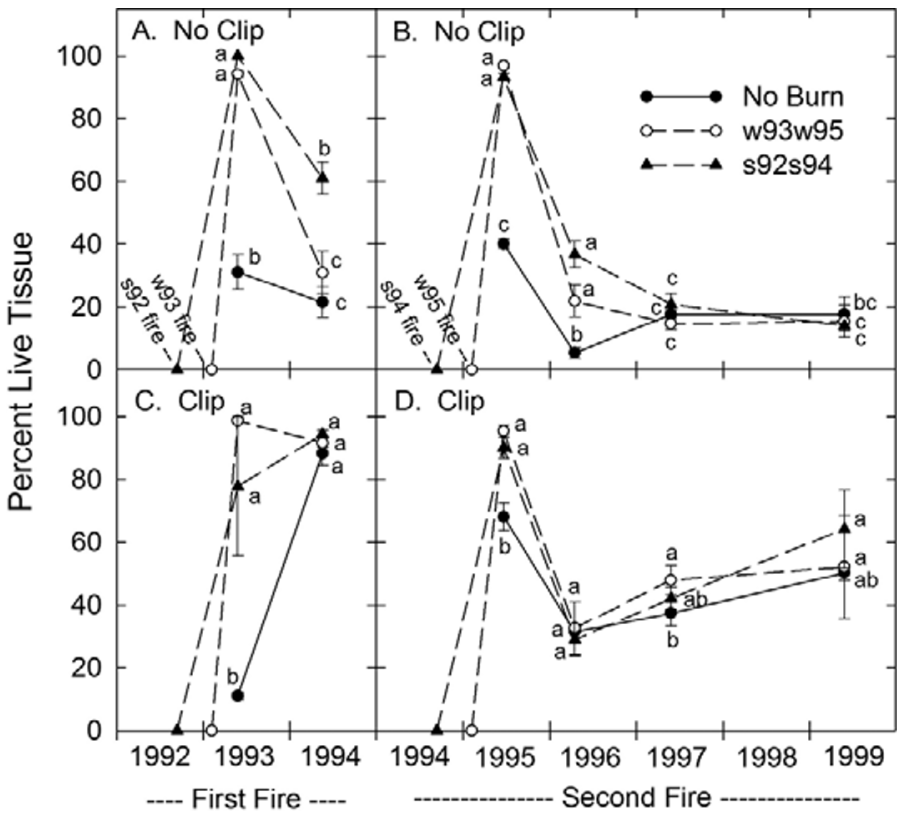

Figure 5. Sideoats grama spring-season (Experiment 2) percentage of live tissue in unclipped and clipped treatments within fire treatments. Different letters across vertical panels within each year indicate significant differences between treatments; Fisher's protected LSD $(P<0.05)$. Vertical lines are $\pm 1 \mathrm{SE}$. Other details are the same as in Figure 2.

(1995) (Fig. 3D). Spring total yield increased in the summer-fire treatment until it exceeded the no-burn and winter-fire treatments at 5 years after the second fire (1999) (Fig. 3D).

Live yield was lowest in summer-fire treatments at the first spring after the s92 or w93 fires (1993) (Fig. 4A) and at the first spring after the s94 and w95 fires (1995) (Fig. 4B). Clipping reduced live yield in the no-burn in 1994 and 1997 and in the winter-fire treatment in 1995 and 1999 but not in the summerfire treatment (Figs. 4A vs. 4C; 4B vs. 4D). Comparing fire treatment effects in clipped plots, spring live yield increased in the summer-fire treatment until it exceeded the no burn and winter-fire treatments at 5 years after the second fire (1999) (Fig. 4D).

Percentage of live tissue was greater in both the summer- and winter-fire treatments than in the no-burn treatment during the first spring after the s92 or w93 fires (1993) (Fig. 5A) and during the first spring after the s94 or w95 fires (1995) (Fig. $5 \mathrm{~B})$. This difference decreased the second year postfire after both the first and second set of fires. Clipping increased the percentage of live tissue in the no-burn and summer- and winter-fire treatments at 2 years after the s92 or w93 fires (1994) (Fig. 5A vs. 5C) and at 3 years after the s94 or w95 fires (1997) (Fig. 5B vs. 5D). Comparing fire treatment effects in clipped plots, percentage of live tissue was greater in both summer- and winter-fire treatments than in the no-burn treatment during the first spring after the s92 or w93 fires (1993) (Fig. 5C) and during the first spring after the s94 or w95 fires (1995) (Fig. 5D).

Effect size coefficients indicated that sample year had a profound effect on all spring yield components, often exceeding that of the fire and clipping treatments (Table 2). Among the imposed independent variables of fire and clipping, fire had 
Table 2. Effect size $\left(\eta_{p}{ }^{2}\right)$ of year, fire, clipping, and fire $\times$ clipping interaction on the 3 response variables during 1-2 years postfire (1993 and 1994 after the first fire; 1995 and 1996 after the second fire), at 3 and 5 years postfire (1997 and 1999), and during the entire study period (1993-1997 and 1999).

\begin{tabular}{llccc}
\hline & & \multicolumn{3}{c}{ Effect size $\left(\eta_{p}{ }^{2}\right)$} \\
\cline { 3 - 5 } Response & & $\begin{array}{c}1-2 \mathrm{y} \\
\text { postfire } \\
\text { variable }\end{array}$ & $\begin{array}{c}\text { 3 and } 5 \mathrm{y} \\
\text { postfire }\end{array}$ & $\begin{array}{c}1-5 \mathrm{y} \text { postfire } \\
(1993-1997, \\
(1993-1996)\end{array}$ \\
\hline Total yield & Effect & 0.878 & 0.784 & 0.760 \\
& Year & 0.925 & 0.531 & 0.805 \\
& Clip & 0.801 & 0.850 & 0.870 \\
& Fire $\times$ clip & 0.286 & 0.494 & 0.427 \\
Live yield & Year & 0.828 & 0.802 & 0.769 \\
& Fire & 0.742 & 0.259 & 0.449 \\
& Clip & 0.654 & 0.101 & 0.571 \\
Percentage of & Year $\times$ clip & 0.258 & 0.336 & 0.407 \\
live tissue & Fire & 0.867 & 0.110 & 0.867 \\
& Clip & 0.917 & 0.042 & 0.852 \\
& Fire $\times$ clip & 0.621 & 0.813 & 0.796 \\
& & 0.499 & 0.046 & 0.294 \\
\hline
\end{tabular}

a greater effect on total yield, live yield, and percentage of live tissue than did clipping or the fire $\times$ clip interaction during the period extending from 1 to 2 years postfire (1993-1994 or 1995-1996). However, during the period extending from 3 to 5 years postfire (1997-1999), clipping had the greatest effect on total yield and percentage of live tissue, whereas live yield was most affected by the fire $\times$ clip interaction. Over the entire study period, the clip treatment had the greatest effect on total and live yields, whereas the fire treatment had the greatest effect on percentage of live tissue. The combined effects of clipping and burning had the least effect on all 3 yield components.

\section{Foliar Cover and Bare Ground Responses}

There were significant 3 -way fire $\times$ clip $\times$ year interactions for sideoats grama foliar cover, and significant 2 -way fire $\times$ year or clip $\times$ year interactions for percentage of bare ground. The summer 1992 and winter 1993 fires decreased sideoats grama cover to $<20 \%$ and $<40 \%$, respectively, in both clipped and unclipped treatments the first growing season postfire (1993) (Fig. 6). Postfire recovery of cover was significantly delayed in the summer-fire treatment compared with the winter-fire treatment. Complete recovery of sideoats grama cover in both clipped and unclipped treatments occurred by 1996, 2 years after the second set of fires (s94, w95), although it may have occurred earlier because 1995 data were not available.

The summer 1992 fire + clip treatment temporarily increased bare ground to $>40 \%$ during the first 2 years postfire (Fig. 7). Bare ground decreased in the winter-fire treatment more rapidly following fire than it did in the summer-fire treatment, especially when plots were not clipped. Bare ground was significantly greater in the summer fire + clip treatment than in the no-burn treatment in 1997, but these differences disappeared by 1998 .

Forb cover ranged from 0 to $5 \pm 0-2 \%$ SE in unclipped, noburn control plots throughout the study (data not shown). Forb

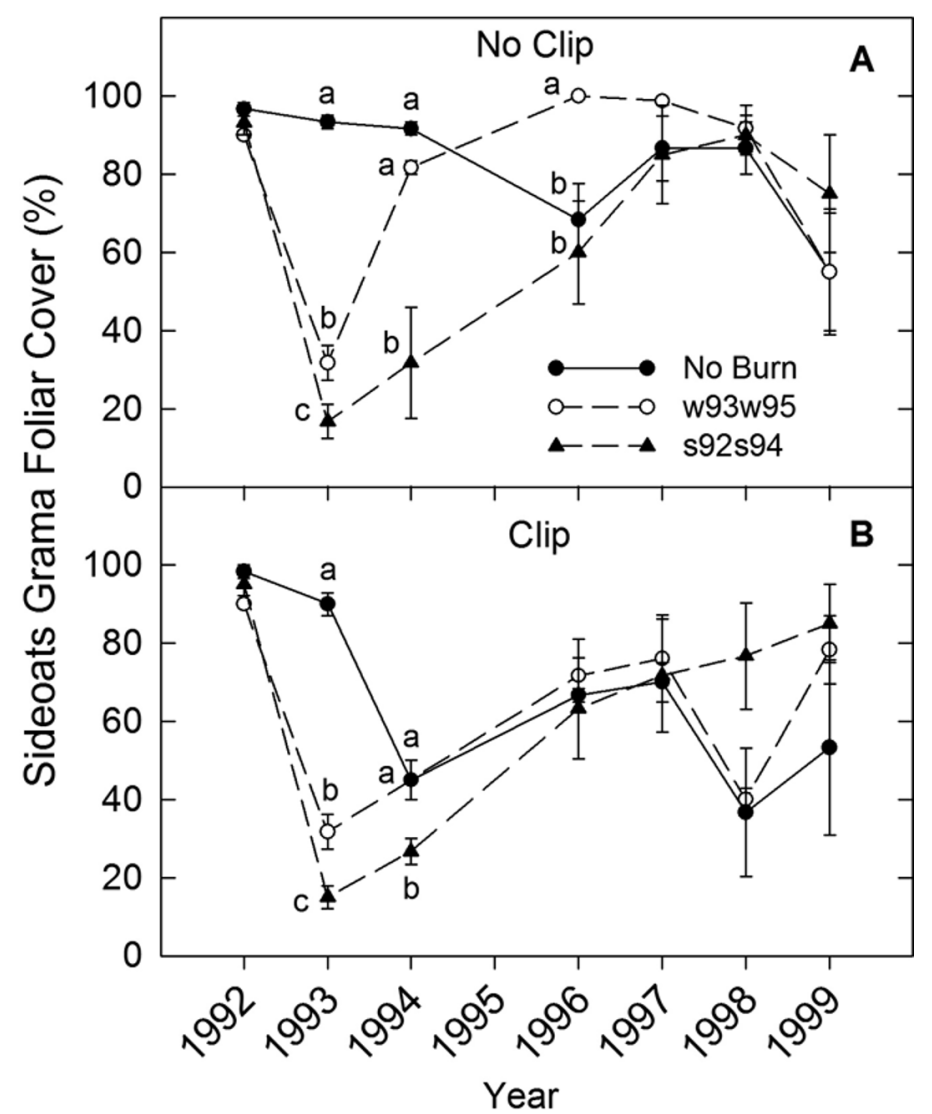

Figure 6. Sideoats grama foliar cover in unclipped and clipped treatments within fire treatments. Different letters within each year in each panel indicate significant differences between treatments; Fisher's protected LSD $(P<0.05)$. Vertical lines are \pm 1 SE.

cover was slightly elevated $(P<0.10)$ in unclipped, summerfire plots at $2(10 \pm 3 \% \mathrm{SE})$ and 3 years $(12 \pm 4 \% \mathrm{SE})$ after the first summer-fire, and at 2 years $(13 \pm 3 \% \mathrm{SE})$ after the second summer fire. Forb cover was elevated $(P<0.10)$ in the clipped, no-burn plots in 1996 (12 $\pm 2 \% \mathrm{SE})$ and in 1997 $(28 \pm 4 \% \mathrm{SE})$. Cover of all other grass species remained below $10 \%$ throughout the study and showed no consistent patterns relative to any treatment. There was no indication that cover of forbs or other grass species increased by the combined effects of burning and clipping.

\section{DISCUSSION}

In the absence of clipping, sideoats grama end-of-growingseason total and live yields recovered from winter fires by 2 years postfire but never exceeded levels in the no-burn treatment during the 2-year postfire period after the w93 fire or during the 3 years after the w95 fire (Fig. 2). This disagrees somewhat with the findings of Knapp et al. (1998), who indicated that aboveground net primary production (ANPP) of $\mathrm{C}_{4}$ grasses in Tallgrass Prairie increased for 2-3 years postfire if water availability was adequate, but is more in line with studies in Africa with the $\mathrm{C}_{4}$ grass, Themeda triandra (Everson et al. 1985), and with several $\mathrm{C}_{4}$ grasses in the Great Plains of the United States (Engle and Bidwell 2001), where quick 


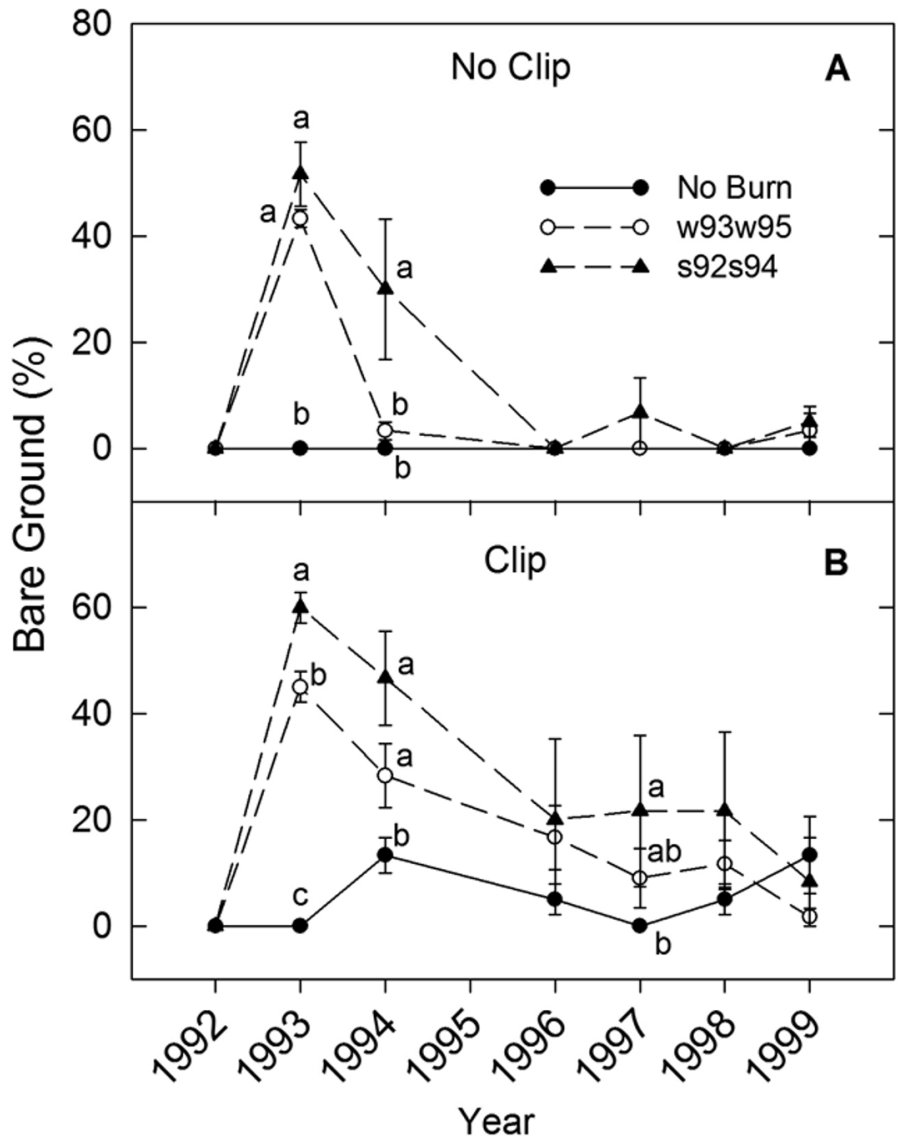

Figure 7. Percentage of bare ground in unclipped and clipped treatments within fire treatments. Different letters within each year in each panel indicate significant differences between treatments; Fisher's protected LSD $(P<0.05)$. Vertical lines are \pm 1 SE.

total biomass recoveries following winter fires were found. In contrast, Bennett et al. (2002) found, in Australia, that Themeda total biomass did not fully recover from a late dormant-season fire until 3 years postfire. Similarly, Wright (1974) found, in Texas, that yields of the rhizomatous growth form of sideoats grama were reduced the first 2 years after winter fires. That form of sideoats grama may be more susceptible to fire than the semibunchgrass form we studied.

The end-of-growing-season data (Experiment 1; Fig. 2) would lead us to reject Hypothesis 1, that winter fires will enhance sideoats grama yields. However, the spring-yield data from Experiment 2 indicate that, in the absence of clipping, total and live yields in the winter-fire treatment exceeded that in the no-burn treatment at 5 years postfire (Figs. 3B and 4B). Therefore, we fail to reject Hypothesis 1.

Relative to our second hypothesis, postfire recovery of sideoats grama total and live yields in the absence of clipping was indeed slower following summer fires than following winter fires (Figs. 2A-C, 3A-B, and 4A-B). However, in the long term (i.e., 5 growing seasons postfire), spring total yield in the summer-fire treatment was similar to that in the winter-fire treatment and greater than that in the no-burn treatment (Fig. 3B). Therefore, we reject Hypothesis 2, that summer fires will reduce sideoats grama, but fail to reject this hypothesis when considering shorter postfire durations.
In Africa, Everson et al. (1985) and Trollope (1987) found that biomass recovery of Themeda triandra was slower following summer fires than following winter fires. Several studies of summer fire in the Tallgrass Prairie of the United States found a decline in $\mathrm{C}_{4}$ grass production during the first year after a summer fire but also found a recovery to preburn or unburned control levels by the second or third year (Engle et al. 1998; Engle and Bidwell 2001). The slower recovery of sideoats grama at our mixed-grass prairie site following summer fire, compared with what is typically found in the Tallgrass Prairie (Engle and Bidwell 2001), is likely due to the greater aridity and variability in precipitation events at our study site compared with Tallgrass Prairie sites.

The enhanced yield of sideoats grama after either winter or summer fire at 5 years postfire may have been due to other firemediated factors, such as increases (Christensen and Muller 1975) or decreases (Knapp et al. 1998) in nutrient availability or increased root growth (Rice et al. 1998). The sharp decline in total and live yields in the no-burn treatment from 1997 to 1999 (Figs. 3B and 4B) suggests that sideoats grama on unburned rangeland was negatively affected by the 1998 drought and that fire a few years before the drought increased this species' resistance to drought.

\section{Fire and Clipping Interactions}

A comparison of clipping effect on each of the 6 postfire sample dates revealed that clipping significantly reduced total yields on 5 dates and live yields on 2 dates in both the no-burn and winter-fire treatments (Figs. 3 and 4). Thus, winter fire + clipping was no more detrimental to grass yield than was clipping alone. In the summer-fire treatment, clipping significantly reduced total yield on only 1 date (1994; Fig. 3), and did not reduce live yields on any date (Fig. 4). Therefore, within the context of the spring-only clipping regime imposed in this study, we reject Hypothesis 3 that the combined effects of summer fire + periodic defoliation by clipping will reduce yields to a greater degree than that from summer fire alone.

Table 2 shows a lower effect size $\left(\eta_{p}{ }^{2}\right)$ for the fire $\times$ clip interaction than for the single effects of fire, clip, or year. These results are consistent with fire and grazing studies from Arizona and New Mexico that found fire and grazing affected vegetation relatively independently (Valone and Kelt 1999; Drewa and Havstad 2001; Valone 2003). However, it is important to note that the lack of a combined clipping + fire effect found in our study is within the context of highly controlled, smallplot treatments. At larger scales (pasture or landscape), where herbivores simultaneously have free access to burned and unburned areas, the grazing + fire interaction may be more important than either grazing, fire, or the sum of their individual effects (Knapp et al. 1998; Fuhlendorf and Engle 2004; Archibald et al. 2005).

A possible reason why the summer fire + clipping was statistically no more detrimental to total yield than that of summer fire alone was because the summer-fire treatment had initially lowered total yields to such a degree that the additional defoliation from annual spring clipping did not further decrease total yield, as was found in the winter-fire and no-burn treatments. We cannot, however, use the same logic regarding live yields because live yields in the summer-fire only treatment 
were, in most years, within the range of the live yields of the no-burn and winter-fire treatments (Fig. 4).

The increased percentage of live tissue for a few years following a fire is consistent with many studies (Knapp et al. 1998). However, we also found that percentage of live tissue was often greater following summer fires than winter fires, especially at the end of the growing season (Fig. 2). Because combustion was complete in all fire treatments, these differences were likely due to differences in postfire regrowth, but physiological reasons for this difference are unknown.

\section{MANAGEMENT IMPLICATIONS}

Several years may be needed following summer fire before sideoats grama and similar $\mathrm{C}_{4}$ grasses can fully recover total standing mass (Engle et al. 1998; Engle and Bidwell 2001). However, in the long term ( 5 years), summer fire in combination with high-intensity, low-frequency defoliation from grazing may stimulate $\mathrm{C}_{4}$ midgrass production over that of winter fire + grazing or grazing alone. Prescribed summer fire may, thus, have application in ecosystems worldwide where woody encroachment is significant, but more expensive chemical and mechanical treatment options are not economically viable (Trollope 1987; van Wilgen et al. 1990; Hodgkinson 1991; Ansley and Taylor 2004). Because herbaceous recovery is likely to be slower after summer fire than after winter fire, one management strategy to increase fire-return intervals on large management units may be to combine the use of winter and summer fires, where winter fires are applied on larger areas to maintain suppression of light densities of brush, and summer fires are used in smaller units that have more significant woody encroachment.

The clipping regime imposed in our study simulated a highintensity, low-frequency grazing pattern. With this arrangement, the first postfire clip treatment occurred about 7 months following each summer fire (i.e., no clipping from October through April) and 2-3 months after the winter fires. Thus, we cannot determine how sideoats grama would have responded to continuous grazing with little or no deferral after fire, or to other sequences of clipping (or grazing) intensity or frequency. However, because the data show that recovery was initially slower following summer fires than winter fires, we hypothesize that any grazing immediately following summer fires would have further delayed recovery (Trollope 1987).

An important consideration in contrasting summer and winter fire effects is ground cover. The summer-fire treatment clearly had a greater effect on decreasing sideoats grama foliar cover and increasing bare ground than did the winter-fire treatment. Although this was only a temporary response that lasted for 2 years postfire, it did leave rangeland exposed to potential erosion for a longer period of time following summer fires than winter fires, and this must be weighed in any decisions regarding the use of summer fires. Other studies worldwide (Trollope 1980; Bailey 1988; De Luis et al. 2004) have issued a similar concern regarding summer fires.

\section{ACKNOWLEDGMENTS}

We thank Betty Kramp, David Jones, Gerral Schulz, and Tim Tunnell, who assisted with treatment implementation and data collection, and Darrell
Ueckert and Charles A. Taylor, Jr., for reviewing earlier drafts of this manuscript.

\section{LITERATURE CITED}

Ansley, R. J., and P. W. Jacoby. 1998. Manipulation of fire intensity to achieve mesquite management goals in north Texas. In: L. Pruden and L. A. Brennan [EDS.]. Fire in ecosystem management: Shifting the paradigm from suppression to prescription. Proceedings of the Tall Timbers Fire Ecology Conference; 7-10 May 1996; Boise, ID. Lawrence, KS: Allen Press 20:195-204.

Ansley, R. J., AND C. A. TAyLOR. 2004. The future of fire as a tool for managing brush. In: W. T. Hamilton, A. McGinty, D. N. Ueckert, C. W. Hanselka, and M. R. Lee [EDS.]. Brush management-Past, present, future. College Station, TX: Texas A\&M University Press. p 200-210.

Ansley, R. J., D. L. Jones, T. R. Tunnell, B. A. Kramp, and P. W. Jacoby. 1998. Honey mesquite canopy responses to single winter fires: relation to herbaceous fuel, weather and fire temperature. International Journal of Wildland Fire 8:241-252.

Ansley, R. J., W. R. Teague, W. E. Pinchak, B. A. Kramp, and D. L. Jones. 2004. Longterm grass yields following chemical control of honey mesquite. Journal of Range Management 57:49-57.

Archibald, S., W. J. Bond, W. D. Stock, and D. H. K. Falrbanks. 2005. Shaping the landscape: fire-grazer interactions in an African savanna. Ecological Applications 15:96-109.

AxELROD, D. I. 1985. Rise of the grassland biome, central North America. Botanical Review 51:163-202.

Balley, A. W. 1988. Understanding fire ecology for range management. In: P. T. Tueller [ED.]. Vegetation science applications for rangeland analysis and management. Boston, MA: Kluwer Academic Publishers. p 527-557.

Bennett, L. T., T. S. Judd, AND M. A. Adams. 2002. Growth and nutrient content of perennial grasslands following burning in semi-arid, sub-tropical Australia. Plant Ecology 164:185-199.

Bond, W. J., F. I. Woodward, and G. F. Midgley. 2005. The global distribution of ecosystems in a world without fire. New Phytologist 165:525-538.

Briggs, J. M., A. K. Knapp, J. M. Blair, J. L. Heisler, G. A. Hoch, M. S. Lett, and J. K. McCarron. 2005. An ecosystem in transition: causes and consequences of the conversion of mesic grassland to shrubland. BioScience 55:243-254.

Christensen, N. L., and C. H. Muller. 1975. Effects of fire on factors controlling plant growth in Adenostoma chaparral. Ecological Monographs 45:29-55.

De Luis, M., J. Raventos, J. Cortina, J. C. Gonzalez-Hildago, and J. R. Sanchez. 2004. Fire and torrential rainfall: effects on the perennial grass Brachypodium retusum. Plant Ecology 173:225-232.

Drewa, P. B., And K. M. Havstad. 2001. Effects of fire, grazing, and the presence of shrubs on Chihuahuan desert grasslands. Journal of Arid Environments 48: 429-443.

Engle, D. M., And T. G. Bidwell. 2001. Viewpoint: The response of central North American prairies to seasonal fires. Journal of Range Management 54:2-10.

Engle, D. M., R. L. Mitchell, and R. L. Stevens. 1998. Late-growing season fire effects in mid-successional tallgrass prairies. Journal of Range Management $51: 115-121$.

Everson, C. S., T. M. Everson, and N. M. Tainton. 1985. The dynamics of Themeda triandra tillers in relation to burning in the Natal Drakenberg. Journal of the Grassland Society of South Africa 2:18-25.

Frost, C. C. 1998. Presettlement fire frequency regimes of the United States: a first approximation. In: $\mathrm{L}$. Pruden and L. A. Brennan [EDS.]. Fire in ecosystem management: Shifting the paradigm from suppression to prescription. Proceedings of the Tall Timbers Fire Ecology Conference; 7-10 May 1996; Boise, ID. Lawrence, KS: Allen Press 20:70-81.

FuHLENDORF, S. D., AND D. M. Engle. 2004. Application of the fire-grazing interaction to restore a shifting mosaic on tallgrass prairie. Journal of Applied Ecology 41:604-614.

Hodgkinson, K. C. 1991. Shrub recruitment response to intensity and season of fire in a semi-arid woodland. Journal of Applied Ecology 28:60-70.

Knapp, A. K., J. M. Briggs, J. M. BlaiR, and C. L. TuRner. 1998. Patterns and controls of aboveground net primary production in Tallgrass prairie. In: A. K. 
Knapp, J. M. Briggs, D. C. Hartnett, and S. L. Collins [EDs.]. Grassland dynamics-Long-term ecological research in Tallgrass Prairie. New York, NY Oxford University Press. p 193-221.

Koos, W. M., J. C. Williams, And M. L. Dixon. 1962. Soil survey of Wilbarger County, Texas. Fort Worth, TX: USDA Soil Conservation Service, Soil Survey Series 18.

[NOAA] National Oceanic and Atmospheric Administration. 2004. Vernon, TX, United States. Asheville, NC: National Climate Data Center. Available at http:// www.ncdc.noaa.gov/oa/ncdc.html. Accessed 16 April 2005.

Rice, C. W., T. C. Todd, J. M. Blair, T. R. Seastedt, R. A. Ramundo, and G. W. T. Wilson. 1998. Belowground biology and processes. In: A. K. Knapp, J. M. Briggs, D. C. Hartnett, and S. L. Collins [EDS.]. Grassland dynamics-Long-term ecological research in Tallgrass Prairie. New York, NY: Oxford University Press. p 244-264.

SPSS [COMPUTER PROGRAM]. 2003. Release 12.0.0. Chicago, IL: SPSS Inc.

Stubbendieck, J., S. L. Hatch, and C. H. Butterfield. 1992. North American range plants. Lincoln, NE: University of Nebraska Press. $493 \mathrm{p}$.

TABACHnick, B. G., And L. S. Fidell. 2001. Using multivariate statistics. 4th ed. Boston, MA: Allyn and Bacon. $966 \mathrm{p}$.

[TFSS] Texas Foundation Seed Service. 2005. Pasture grasses and forbs. Available at: http://tfss.tamu.edu/pasture_grasses.htm. Accessed: 15 November 2005.

ThornBuRg, A. A. 1982. Plant materials for use on surface-mined lands in arid and semi-arid regions. Washington, DC: USDA Soil Conservation Service SCS-TP157

TROLLOPE, W. S. W. 1980. Controlling bush encroachment with fire in the savanna areas of South Africa. Proceedings of the Grassland Society of South Africa 15:173-177.

Trollope, W. S. W. 1984. Fire in savanna. In: P. de V. Booysen and N. M. Tainton [EDS.]. Ecological effects of fire in South Africa ecosystems: Ecological studies 48. Berlin-Heidelberg, Germany: Springer-Verlag. p 149-175.

TROLLOPE, W. S. W. 1987. Effect of season of burning on grass recovery in the false thornveld of the eastern Cape. Journal of the Grassland Society of South Africa 4:74-77.

VALONE, T. J. 2003. Examination of interaction effects of multiple disturbances on an arid plant community. Southwestern Naturalist 48:481-490.

Valone, T. J., AND D. A. Kelt. 1999. Fire and grazing in a shrub invaded arid grassland community: independent or interactive effects? Journal of Arid Environments 42:15-58.

Van Auken, 0. W. 2000. Shrub invasions of North American semiarid grasslands. Annual Review Ecology and Systematics 31:197-215.

van Wilgen, B. W., C. S. Everson, and W. S. W. Trollope. 1990. Fire management in southern Africa: some examples of current objectives, practices and problems. In: J. G. Goldhammer [ED.]. Fire in the tropical biota-Ecosystem processes and global challenges. Berlin, Germany: Springer-Verlag, Berlin. p 179-215.

WRIGHT, H. A. 1974. Effect of fire on southern mixed prairie grasses. Journal of Range Management 27:417-419.

Wright, H. A., And A. W. Bailey. 1982. Fire ecology. New York, NY: John Wiley and Sons. 501 p. 